\title{
THE HEGEMONY OF WHITE COMMODITY CULTURE TOWARD AFRO-AMERICAN: AN ANALYSIS OF SUSAN WILLIS' I SHOP THEREFORE I $A M$
}

\author{
Irma Windy Astuti \\ Islamic University of Indonesia
}

\begin{abstract}
This paper is meant to analyze Willis' work which underlines the influence of commodity culture of mainstream white society in America towards other race, particularly Afro-American as one of the country's minority races in the 1980 's. The work further posits that the white America's popular and mass culture has ingrained and legitimately shaped the way Afro-American see and value their own culture and self identity, and that its spread and control is both political and materialistic. This paper is seek to put forward that Willis' idea can be visibly viewed through and associated with Gramsci's theory of hegemony in understanding the underlying agenda advocated by the more superior group (white) towards their subordinate counterparts (AfroAmerican).
\end{abstract}

Key words: white mass culture, afro-American, hegemony.

\section{INTRODUCTION}

In I Shop therefore I am, Susan Willis is pointing on a bitter reality faced by African-Americans whose race and culture are still being marginalized by the socalled white dominated culture industry by way of celebrating and identifying themselves with it. Willis argues that American mass and commodity culture have massively influenced the daily lives of Afro-American, and only turn them into its faithful consumers owning so little room to actively participate in producing alternative culture 
In her work Willis presents many examples of cultural phenomena - of the past and the present time- in order for her to reveal the subtle and tricky domination by the white culture industry over the racial "others" particularly Afro-American.

\section{DISCUSSION}

In drawing on one of the examples of white influences towards AfroAmerican in the past, Willis is especially interested in highlighting the theme of Toni Morrison's first novel The Bluest Eye set in working-class neighborhood of the 30s and 40s which portrays the social norms of American cultures imposed on African Americans that consequently contribute to their fragmentation, alienation, and the loss of community, as well as of identity. From the Bluest Eye, Willis suggests that it is hard to reject the standards immensely set by white through its mass media that it "forces" black people to make "adjustments" in order to be equally happy.

From literature, Willis moves into today mass media culture - advertisements and magazines- and finds that white cultural hegemony has taken itself in more complex fashions. She particularly stresses the reality in the consumer society where the country's white-dominated fashion industries have been quite successful in making their consumers to believe that by using their particular products and brands, people have created for themselves new notion and specific identity. Many consumers, including blacks have bought this idea. They purchase and use brand names which actually 'say' nothing about them. The mass media and fashion industries' use of black models and celebrities to advertise their products is nothing more than a strategy to lead as many blacks as possible to purchase their new identity, white identity. "... the corporations are as white as the interests and culture of the ruling class..." (Willis in Warhol and Herndl, 1997: 995).

Willis further argues that the industries are particularly aiming to make nonwhite women their target market. The more dominant "white look" of the contemporary America has resulted in considerable association with it, by which women of racial "others" find their "new identity" and solution to their otherness.

This is, buy a new you. Transform yourself by piling on as many brand name styles... The solution to a racist society is a "pretty little black skinned girl" ", and "...the suggestion that women with the proper "look" are equally "raced" (Willis in Warhol and Herndl, pp: 996 \& 1000). 
Accordingly, that is essentially the idea behind "I Shop Therefore I Am" originally a motto accompanying a photograph by Barbara Kruger- in which it equalizes shopping to mere existence, therefore, "the purchase of brand names is the individual's means for designating a specific identity" (Willis in Warhol and Herndl,pp. 994). In addition, the industries' transaction on the "look" is as the same time, according to Willis, pronounces their sexist nature. Even so, Willis further states that "...the victimization, the sexism, the degradation and dehumanization- all go unnoticed because the notion of consumption is synonymous with gratification" (997). And, as a consequence, many AfroAmericans willingly submit themselves to the mainstream culture and contently become its replicas. This inevitably “ ... denies the possibility for articulating cultural diversity precisely because it demonstrates that the difference is only a matter of fashion" and particularly, “... smothers the possibility for creating black cultural alternatives" (1000).

Another striking example of white authority, according to Willis, is that there is recently an attempt made by the fashion industries to create and promote the socalled "new ethnicity", the look of racial homogeneity as yet, another, " different approach to racism in society" (pp.1000). Willis refers to,

Elle magazine featured a beige woman... whose features, skin tone and hair suggest no one race... She is instead all races in one... is the industry's metaphor for the magical erasure of race as a problem in our society. It underscores white supremacy without directly invoking the dominant race (p.1000).

By analogy, as Willis' next catch is none other than Michael Jackson whom she sees as "the quintessential mass cultural commodity...who articulates whiteness and blackness as surgical rather than cultural identities, offers an easy solution to racial conflict (pp. 1000-1001). Put another way, Willis does not see Michael Jackson as one of the most successful Afro-Americans, rather she sees him especially concerning with his physical transformations, "as a consummate expression of the commodity form" (pp.1001). Thus, "Rather than making a social statement, Jackson states himself as a commodity...This interpretation sees the commodity form as the denial of difference" (pp.1002).

Finally, all the examples posed by Willis suggest a devastating cancellation of the desire for black expression in mass culture, which by its very definition is white culture. 
This is more or less my position. I agree with Willis whom sees white culture as hegemonic. Its "control" of other race and culture easily shows white's fear of difference for difference is dangerous. As the dominant social groups, it is likely that they want to ensure and secure their supremacy and make the others subordinate to them. Gramsci's theory of hegemony is therefore relevant to the analysis of white domination over racial others, particularly Afro-American in its commodity culture. Gramsci's understanding of hegemony as a cultural and ideological means whereby the dominant groups in society maintain their dominance by securing the 'spontaneous consent' of the subordinate groups ( Strinati, $1995: 165)$. As a matter of fact, it is all true in liberal and pluralist country likeAmerica. According to Lefebvre in Mattlelart's :

Yet, liberal pluralism itself is systematic and dogmatic in its own way. The number of accepted opinion is few; liberal accepts several moral codes, but demand some kind of morality (1989: 76).

For that reason, the ruling social group does whatever it can to control and prevent the alternatives viewpoints from emerging. And one way to do it is by making "agreements". One of the most recent interpreters of Gramsci's work, provide the following summary:

Gramsci uses the concept of hegemony to describe the various modes of social control available to the dominant social group. He distinguishes between coercive control...., and consensual control which arises when individuals 'willingly' or 'voluntarily' assimilate the world-view or hegemony of the dominant group; an assimilation which allows that group to be hegemonic. (Ransome in Strinati, 1995 :165-166).

To borrow from Strinati's "negotiated construction" or consensus is the term best to illustrate the phenomenon presented in Willis's essay related to white culture's successful attempts in forming a new, yet white, identity for AfroAmericans by which they feel "equally raced". The sense of "equally raced" certainly generates feeling of being acknowledged and welcomed into the larger group, and makes it the 'we' group. As stated by Hofstede, " The 'we' group is the major source of one's identity, and the only secure protection one has against hardships" (1991 : 50). As Willis further implies, such security - derived from the new identity provided by agents of white mass-culture - is only superficial. It is also true according to Mattlelart. 
We should begin by pointing out that it has long been recognized by cultural critics that mass-culture brings together a variety of different areas: the 'real' and the 'imaginary'... The boundary between reality and fiction becomes progressively vaguer... The effect of fictional standards ...can be seen in most women's radio or television broadcasts... A life-style is more easily transmitted fictionally than non-fictionally... This zone of mass-culture is the privileged space where authority does not need to speak politically in order to act politically (1982: 78).

The incorporation and internalization of style and life-style by American culture industry into mainstream culture and into the daily life of Afro-Americans have made black people "assimilates race to style" (Willis in Warhol and Herndl, pp:1000) and therefore, make them think that the only possible different is in the level of styles and fashions. And it has been seemingly internalized and proven to be successful in America's consumer society. As one of the fashion magazine editors put it, " selling product is dead, but selling life-styles is long lasting." It is since life-style can be made and perceived as equal to self identity and self affirmation. Such reality seems to outline the concept of commodity fetishism. Fetishism is phenomenon of social consciousness and of social being" (Rubin in Perlman,1968). In addition, as cited in Pearlman, Marx's noted that in a case of commodity fetishism, social relations among people simply "appear" to take the form of things; they merely seem to be a reification, a "mystification", and he attributes it to "the habit of everyday life" ( Ibid: 37 ). In other words, As Adorno and Horkheimer put it:

The culture industry perpetually cheats its consumers of what it perpetually promises... The promise,... is illusory: all it actually confirms is that the real points will never be reached, that the diner must be satisfied with the menu (1997: 139)

Willis also stresses that Michael Jackson and his transformations is an expression of commodity form equalizing him with the other products of America's popular and mass culture. As stated by Strinati:

Popular culture and mass media are subjects to the production, reproduction and transformation of hegemony through the institutions... which cover the areas of cultural production and consumption... which characterize mature liberal democratic, capitalist societies (1995:168). 
In that sense, Michael Jackson is in fact a product of white commodity culture and not in a real sense expressing blackness or Afro-American culture since he has been commodified for the purpose of popular culture.

So far, we have been dealing with white hegemony in portraying the face of Afro-American culture. In addition to that, I argue that economic factors should also be considered upon the spread and affirmation of white culture within AfroAmerican community. It is true when we apply it to a capitalist and pluralist country like America. Take popular and mass-media for example, the pressure of rising costs means that all media have to try to reach as large audience as possible which they can do by aiming at a large mass audience. Equally, they cannot afford to lose audiences in say, a rating war.

In general, then, the determining context for production is always that of the market. In seeking to maximize this market, products must draw on the most widely legitimated central core values... The need for easily understood, popular, formulated, undisturbing, assimilable fictional material is at once a commercial imperative and an aesthetic recipe ( Ibid : 40 in Strinati, pp: 142).

And, since white makes up the majority of American and also the dominant social groups there, the agents of mass and popular culture is bound to make their products available and appealing for the whites. Meanwhile, in considering the rest of the population, including Afro-Americans, we are back with the idea of consensus proposed by Gramsci. The seemingly alternative black culture or any products associated with black figures are then introduced to involve black's participation as consumers in apparently predominant white commodity.

\section{CONCLUSION}

Finally, we seem to know Willis's answer for her own rhetorical question, that it seems hard for Afro-American to find a place in American commodity culture. However, as we go back to Willis' argument concerning with the absence of AfroAmerican culture, I find her being unclear since she gives no exact examples as to how a whole and sustaining Afro-American culture she expects to flourish is like. Willis does implicitly mention about blues music popularized by Southern AfroAmerican which can be considered her example of Afro-American culture finding its place and sustainability in American commodity culture as alternative music. I suggest that American rap music can also be put as another example of successful 
Afro-American culture in American commodity culture. Rap which is also known as black music in fact get noticed by American society and the world in the 1980's when Willis wrote her work. Today's rap music in America is not only being largely associated with black people, but also white and other races. In addition, it gains so much attention and interest from white people that it has been conceived as a mass culture. However, would Willis consider then that rap music to be a kind of Afro-American cultural form capable of bringing its people into fruition? Here, I do not attempt to answer the question, since for the most part Willis has made it clear that perhaps despite the acknowledgment for the existing black culture such as blues music, white hegemony is still so powerful in American popular culture that there seems to be no room for Afro-American culture to let itself grow and sustain. At last, to add in my conclusion, the bitter reality faced by Afro-American culture should make us think of sustaining our very own culture and identity, since America even the world today have become more and more standardized by white American capitalists in term of popular and commodity culture.

\section{REFERENCES}

Adorno, Theodor and Marx Horkheimer. (1997[1947]) "Culture Industry :

Enlightenment as Mass Deception" in Diacletic Enlightenment, trans. John Cumming. London : Verso

Hofstede, Geert. (1991). Cultures and Organizations. New York : McGraw-Hill. Mattelart, Michele. (1989). "Women and the Cultural Industry.". In Collins, Richard. And James Curran. (ed) Media, Culture, and Society. London : Sage Publications

Perlman, Fredy. (1968). Introduction : Commodity Fetishism. Kalamazo

Strinati, Dominic. (1995). An Introduction to Theories of Popular Culture. London: Routledge

Willis, Susan. (1989). "I Shop Therefore I Am." In Warhol, Robyn. and Diane Prince Herndl.(Ed). Feminisms : an Anthology of Literary Theories and Criticism. Livingston : Rutgers University Press. 